June 1923

\title{
A Selection of Cases Under the Interstate Commerce Act
}

Thomas Porter Hardman

West Virginia University College of Law

Follow this and additional works at: https://researchrepository.wvu.edu/wvlr

Part of the Constitutional Law Commons

\section{Recommended Citation}

Thomas P. Hardman, A Selection of Cases Under the Interstate Commerce Act, 29 W. Va. L. Rev. (1923). Available at: https://researchrepository.wvu.edu/wvlr/vol29/iss4/13

This Book Review is brought to you for free and open access by the WVU College of Law at The Research Repository @WVU. It has been accepted for inclusion in West Virginia Law Review by an authorized editor of The Research Repository @WVU. For more information, please contact ian.harmon@mail.wvu.edu. 
does it so well. It deserves a place in every law library and is worthy of a place in the curriculum of every law school. No man, either student or practitioner of law, could read this book without receiving benefit therefrom nor without having higher ideals and a determination to strive to attain them.

I. Grant Lazelie.

Judge of the Seventeenth Judicial

Circuit of West Virginia.

A Selection of Cases Under the Intetstate Commerce Act (2nd ed.)-By Felix Frankfurter, Cambridge: Harvard University Press, 1922, pp. xii, 789.

Perhaps no other phase of the law has undergone greater change in the last few years than that part of public service law which is affected by the dormant or exercised power of Congress to regulate interstate commerce. Professor Frankfurter has therefore rendered a service of the first magnitude not only to the law teacher but to the practitioner by bringing down to date his valuable Seleetion of Cases under the Interstate Commerce Act. The choice of cases, both new and old, is excellent, and the volume is as nearly down to date as it is possible to be, important cases, such as the Wisconsin Rate Case, which appeared while the book was going through the press, being inserted in an appendix.

The paramout importance of this too often neglected part of the law of public utilities is deservedly emphasized in the preface. "According to authoritative estimate the volume of interstate traffic in the United States is about three-fourths of the whole. This means that three-quarters of the country's transportation business,-not to mention other vast interstate utilities, such as the telegraph, the express service, the pipe lines,-are subject to the control of governmental regulation. Ample a priori justification would thus exist for systematic study, according to proved methods of legal education, of that body of law through which this governmental control is exercised."

The reviewer's experience in the class-room use of the book has been that, although the cases are far more difficult reading than the cases in the other parts of public service law, the students take more interest in these cases than in the other public service cases, -and no one can deny the importance of the subject mat- 
ter dealt with in these decisions. Professor Frankfurter is therefore to be congratulated on compiling such a valuable volume on this very vital branch of the law.

Thomas Porter Hardman.

West Virginia University

College of Law. 